\title{
Christine Vogel
}

Guerra aos jesuítas: A propaganda antijesuítica do Marquês de Pombal em Portugal e na Europa. Trans. Cristina Osswald. Lisbon: Temas e Debates-Círculo de Leitores, 2017. Pp. xviii + 589. Pb, €19.90.

In 2006, Christine Vogel published her doctoral thesis on the history of eighteenth-century Portuguese and French anti-Jesuitism: Der Untergang Gesellschaft Jesu als europäisches Medienereignis (1758-1773) (Göttingen: Vandenhoeck \& Ruprecht, 2006). Eleven years later the book was fortunately translated into Portuguese by Cristina Osswald. Given the role played by the Portuguese Crown, and especially by the Marquis of Pombal in the development of a propagandist campaign against the Jesuits, this translation is particularly welcome. Together with José Eduardo Franco's $O$ mito dos Jesuitas em Portugal, no Brasil e no Oriente (séculos XVI a XX) (Lisbon: Gradiva, 2006), Guerra aos jesuitas is definitely one of the most significant works on the Pombaline campaign and its influence in shaping the anti-Jesuit European coetaneous debates. During her doctoral studies, Vogel analyzed numerous sources pertaining to German, French, Italian, Spanish and Portuguese archives, which testifies to the European scope of her endeavor. Besides referring to the most well-known anti-Jesuit booklets published in this period, her main concern was to scrutinize the role of European journals and illustrations in the building and diffusion of the anti-Jesuit debate. Putting journals such as Nouvelles ecclésiastiques, Nouvelles intéressantes, Hamburgische correspondent, and Gazette d'Amsterdam in the center of this account is one of the most significant (and original) contributions of Guerra aos jesuitas for the history of anti-Jesuitism. By focusing on the role played by periodical publications, the argument that the decline of the Society of Jesus was "an efficient moment of intensifying communication" is particularly persuasive (9). The recurrent analysis of visual representations is also one of the most distinctive features of Guerra aos jesuitas. The profusion of anti-Jesuit iconography in this period is especially intriguing given the Jesuits' expertise in visual arts, as the "copiously illustrated editions of the Spiritual Exercises and the luxurious [edition of] Imago primi saeculi" testify (466).

Following an introductory chapter on the history of anti-Jesuitism in the sixteenth and seventeenth centuries, the book proceeds with two chapters on the Portuguese (71-298) and French cases (301-434). More than merely geographical, this division aims at representing the two different phases of the anti-Jesuit debate. In what concerns the Portuguese case, the main argument is 
that the European success of the anti-Jesuit campaign set up by Pombal should not be exclusively attributed to his printing and diplomatic efforts, but should take into account the role played by the network of French and Italian Jansenist periodicals, which overshadowed the few apologetic works published during this period. According to Vogel, renowned Jansenists such as Pierre Olivier Pinault, who translated the anti-Jesuit booklets into French, did not require any incentives to diffuse the Portuguese case to a French audience (138-39). The most important Pombaline contribution for the European debate was the publication of Erros ímpios e sediciosos (1759), a thirty-two-page booklet printed in the aftermath of the conspiracy behind the royal assassination attempt. Following the style and line of reasoning of the popular anti-Jesuit work Monita secreta Societatis Iesu, Erros impios e sediciosos contributed to the building and diffusion of the Jesuits as morally relaxed clerics and supporters of tyrannicide (235-62). Although Claudio Acquaviva had forbidden the Jesuits to defend tyrannicide, either publically or privately, the interpretation of Robert Bellarmine that proclaimed the supremacy of the spiritual authority over the temporal power was clearly predominant in this period. This was particularly significant in building the anti-Jesuit debate, because Bellarmine's argument reinforced the Jansenist accusation of Ultramontanism and, indirectly, the accusation of supporting tyrannicide.

The French case was somewhat different. Notwithstanding the role played by Étienne François Choiseul, the Jesuit affair was not triggered by the crow or the government, but by a sequence of events, namely the conspiracy to kill King Louis XV in 1757, the opposition to the bull Unigenitus and the refusal to administer the Holy Sacraments to Jansenists. During the second phase of the debate, the Histoire générale de la naissance et des progrès de la Compagnie de Jésus (1760) by Louis-Adrien le Page and Christophe Coudrette, and the journal Nouvelles ecclésiastiques were particularly effective in diffusing the Jansenist accusations. This period witnessed the publication of several apologetic writings, such as the Apologie générale de l'Institut et de la doctrine des jésuites, published by Joseph-Antonio-Joachim Cérutti in 1762 and the Extraits des assertions, published by Jean-Nicolas Grou and Henri Sauvage between 1763 and $1765(364-71)$. Nevertheless, this endeavor was insufficient as the Jansenist accusations were broadly diffused and widely accepted in eighteenth-century France. Following a brief chapter on the suppression of the Society of Jesus (437-6o), the book proceeds with comprehensive concluding remarks (46392). The final chapter summarizes the main arguments presented by Christine Vogel and testifies to the global scope and the highest academic standards 
of Guerra aos jesuitas. Given its importance in the field of Jesuit studies, an English translation will be especially welcome.

\section{Francisco Malta Romeiras}

Centro Interuniversitário de História das Ciências e da Tecnologia, Universidade de Lisboa

franciscomesquitella@gmail.com

DOI 10.1163/22141332-00501008-14 